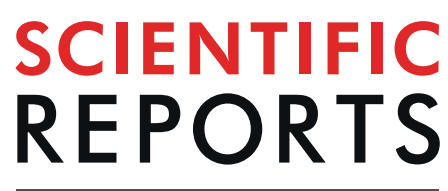

natureresearch

Check for updates

\title{
OPEN Publisher Correction: A genetic analysis identifies a haplotype at adiponectin locus: Association with obesity and type 2 diabetes
}

Sayantani Pramanik Palit, Roma Patel, Shahnawaz D. Jadeja, Nirali Rathwa, Ankit Mahajan, A. V. Ramachandran $(\mathbb{D}$, Manoj K. Dhar, Swarkar Sharma $(1)$ \& Rasheedunnisa Begum (1)

Correction to: Scientific Reports https://doi.org/10.1038/s41598-020-59845-z, published online 19 February 2020

In the original version of this Article, the ORCID ID for Rasheedunnisa Begum was omitted. This has now been corrected in the HTML and PDF versions of the Article.

(c) (i) Open Access This article is licensed under a Creative Commons Attribution 4.0 International License, which permits use, sharing, adaptation, distribution and reproduction in any medium or format, as long as you give appropriate credit to the original author(s) and the source, provide a link to the Creative Commons license, and indicate if changes were made. The images or other third party material in this article are included in the article's Creative Commons license, unless indicated otherwise in a credit line to the material. If material is not included in the article's Creative Commons license and your intended use is not permitted by statutory regulation or exceeds the permitted use, you will need to obtain permission directly from the copyright holder. To view a copy of this license, visit http://creativecommons.org/licenses/by/4.0/.

(C) The Author(s) 2020 